\title{
Transnational Advocacy over Time: Business and NGO Mobilization at UN Climate Summits
}

\author{
Marcel Hanegraaff*
}

A common feature of contemporary domestic and transnational political systems is the extensive and ever-growing participation of interest groups in the policymaking process. ${ }^{1}$ While this observation is widely documented, the consequences of these developments, especially the consequences of opening up international organizations (IOs) to the input of interest groups, are often still poorly understood. ${ }^{2}$ Many proponents argue that opening up to the input of interest groups will result in more proficiency, accountability, and legitimacy. Opponents contend that the inherently biased nature of interest representation could lead more open IOs to capture by special interest groups.

In this article I analyze how and why the interest group communities that lobby during UN climate summits evolved over the past two decades. ${ }^{3}$ I explicitly link the analysis to the broader literature on interest group community development, which generally focuses on domestic political systems. I also connect two literatures that have much in common, yet in practice do not often interact. For example, the interest group literature has produced and tested a set of contrasting hypotheses on the development of these communities in domestic political systems, which show remarkable resemblance to claims made in the more normative oriented literature on international governance. ${ }^{4}$ In line with the opponents of more-open IOs, the collective action perspective claims that the overall participation of interest groups in a maturing interest community will increasingly skew in favor of business and specialized interest

* The research presented in this article was made possible by the Research Foundation-Flanders. I thank the editors, Kate O'Neill and Stacy D. VanDeveer, and three anonymous referees for their valuable comments and their constructive suggestions. I also would like to express my gratitude to all the students and research assistants who helped me with coding and processing the data.

1. Bexell et al. 2010; Beyers et al. 2008; Halpin and Jordan 2012; Hanegraaff et al. 2011; Lowery and Gray 2004; Jönsson and Tallberg 2010.

2. Bexell et al. 2010; Jönsson and Tallberg 2010.

3. E.g., Fisher and Green 2004; Fisher 2010; McGregor 2011; Muñoz Cabré 2011.

4. Gray and Lowery 1996; Lowery 2007; Lowery et al. 2008. 
groups, which usually face fewer collective action problems. ${ }^{5}$ More in line with proponents of more-open IOs, the neopluralist perspective does not refute the existence of collective action problems, but it emphasizes that such problems become less severe over time, which ensures that systems of interest representation eventually will become more diverse. ${ }^{6}$ Despite this overlap in research questions and theoretical interests, there is hardly any cross-fertilization between the literatures on interest group politics and global advocacy.

This article analyzes two research questions. First, regarding the development of skewness in the interest community, does the climate change interest group community become monotonically more skewed over time, monotonically less skewed, or initially more skewed and then less skewed? Second, can we explain this development towards a less or more diverse system from a collective action or a neopluralist perspective?

I analyze these questions using a new dataset consisting of all individual organizations that lobbied at climate conferences $(N=6,665)$ between 1997 and 2011. As many proponents of more-open IOs predicted and much in line with a neopluralist perspective, my results indicate that the interest group system at Conferences of the Parties (COPs) became more diverse over time. However, the balancing took considerable time; during the first ten years of its existence the COP interest community was mostly populated by business, especially concentrated business interests. These findings lead me to conclude that the transnational and domestic interest communities have much in common. Especially the fact that both interest communities first become more biased, after which they become more balanced seems to be a very resilient mechanism in the development of interest communities that seems to transcend the specific conditions of political systems.

\section{Collective Action and Neopluralist Perspectives}

I start with an overview of the two most common perspectives on interest community development. Both collective action and neopluralist perspectives assume that interest groups do not politically mobilize spontaneously and that some types of interest groups mobilize more easily than others. Several factors are thought to create uneven incentives and obstacles in interest group mobilization. Most notably, Olson has argued that small groups with specialized interests are far more likely than large groups with diffuse interests to overcome mobilization obstacles. For the latter, the incentive to free-ride is so powerful that mobilization is highly unlikely. ${ }^{7}$ For instance, lobbying can have a direct effect on the balance sheet of each individual member in a focused business organization. Such tangible and concentrated benefits are much more difficult to identify in larger NGOs, which focus on more diffuse interests such as human

5. Schattschneider 1960; Olson 1965.

6. Berry 1999; Lowery and Gray 2004.

7. Olson 1965; Lowery and Gray 2004. 
rights or the environment. This makes political mobilization for business actors considerably easier. Different types of business organizations confront varying collective action problems, most often depending on the scope of the economic sector represented. Organizations that represent small and specialized segments of the economy, such as the American Corn Growers Association, face considerably fewer obstacles to mobilization compared to organizations that represent multiple or encompassing economic sectors, such as the American Chamber of Commerce. The potential for each individual member to free-ride in the latter case is considerably higher, which substantially increases the coordination costs for encompassing business associations and therefore the ability to become politically active quickly. While other factors are also deemed to ease or frustrate the mobilization of interest groups-such as political opportunity structures, the substance of political agendas, public and political saliency, and specific economic and social developments-collective action problems are generally considered the most important factors affecting how quickly interest groups can become politically active. $^{8}$

The collective action and neopluralist perspectives both hold that these varying obstacles and incentives shape the formation of new interest communities. Interest groups with fewer obstacles and/or more incentives dominate a community, initially causing it to be more skewed. However, in later stages of development, the collective action and neopluralist perspectives diverge.

The collective action perspective continues to stress the importance of collective action problems for the development of the interest community and argues that, other things being equal, if certain interests mobilize more easily in the initial period, they continue to profit from these advantages. This leads to increasingly skewed participation, to the benefit of organizations that face fewer collective action problems. ${ }^{9}$ This approach thus presumes that collective action problems of individual interest groups reverberate in the further development of interest communities. To put it differently, if interest groups of type $A$ face fewer collective action problems than those of type $B$, an interest group community will become increasingly dominated by groups of type $A$ at the expense of groups of type $B$ (Figure 1 ). In many instances, business and specific interests have been found to progressively dominate interest group communities because they usually face fewer obstacles for political mobilization. ${ }^{10}$ One important advantage for interest groups that mobilize earlier in the development of an interest group community is that they are usually better able to institutionalize key advantages, which generally reverberate in the further development of the interest group community. This advantage stems from the fact that first entrants can achieve greater control of resources than followers, and gain vital experiences that newcomers may lack. For instance, if they can create strong contacts with key policy-makers and other stakeholders, they gain

\footnotetext{
8. Nownes 2004; Nownes and Lipinski 2005; Baumgartner and Leech 2001; Lowery and Gray 1996.

9. Carpenter 2004; Braun 2012.

10. For an overview see Lowery et al. 2008, Halpin and Jordan 2012.
} 


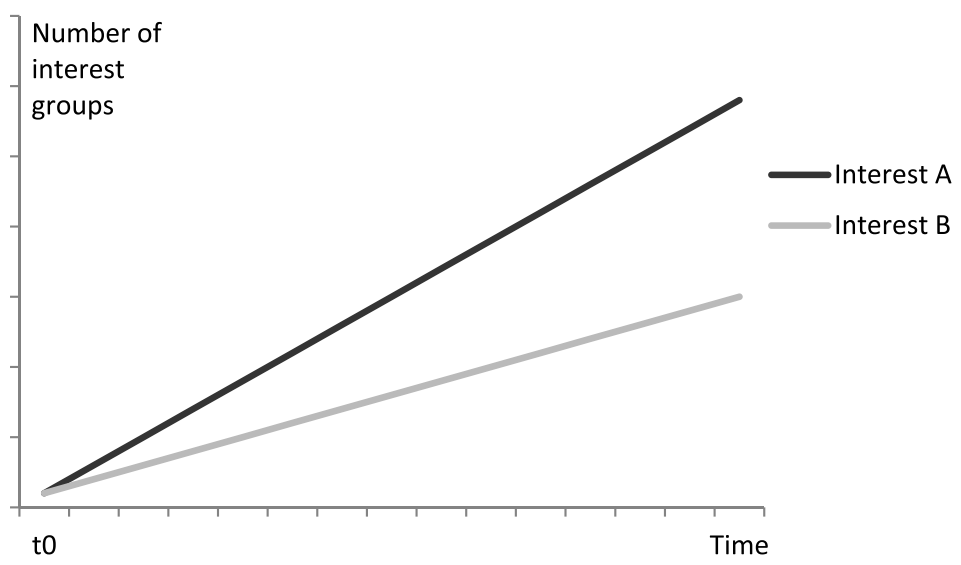

Figure 1

Interest Community Development from the Collective Action Perspective

expertise on crucial policy issues and gain experience on how to lobby effectively. ${ }^{11}$ As such, early mobilization provides additional benefits for organizations in terms of effective representation at political venues.

Neopluralism also expects that some interests will mobilize more easily than others. However, neopluralists hypothesize that inherent balancing mechanisms within interest communities ensure that, over time, representational participation in interest group communities will become less skewed. ${ }^{12}$ The first balancing mechanism relates to the eventual diminishing of collective problems for diffuse interests, through creative leadership ${ }_{1}^{13}$ selective incentives, ${ }^{14}$ wealthy patrons or sponsors, ${ }^{15}$ government subsidies, ${ }^{16}$ etc. For example, many large NGOs are funded by governments, international organizations, or wealthy individuals, which allow the organizations to mobilize despite the various collective action problems they face. As a result, a broader set of interests will be able to become politically active over time. A second balancing mechanism is the "density dependency effect," which dampens the mobilization potential of individual interests as interest communities become denser. ${ }^{17}$ This logic resembles that of an economic market in which consumer demand regulates the maximum number of, for instance, supermarkets and electronics shops in a community. Similarly, the amount of constituency support in a society regulates the number of interest groups able to become politically active on an issue. Each area thus

11. Heinz et al. 1993.

12. Gray and Lowery 1996; Lowery and Gray 2004; Berry 1999.

13. Salisbury 1969.

14. Olson 1965.

15. Walker 1983.

16. Mahoney and Beckstand 2011.

17. Lowery and Gray 1996; Hannan and Carroll 1992; Gray and Lowery 1996; Halpin and Thomas III 2012. 


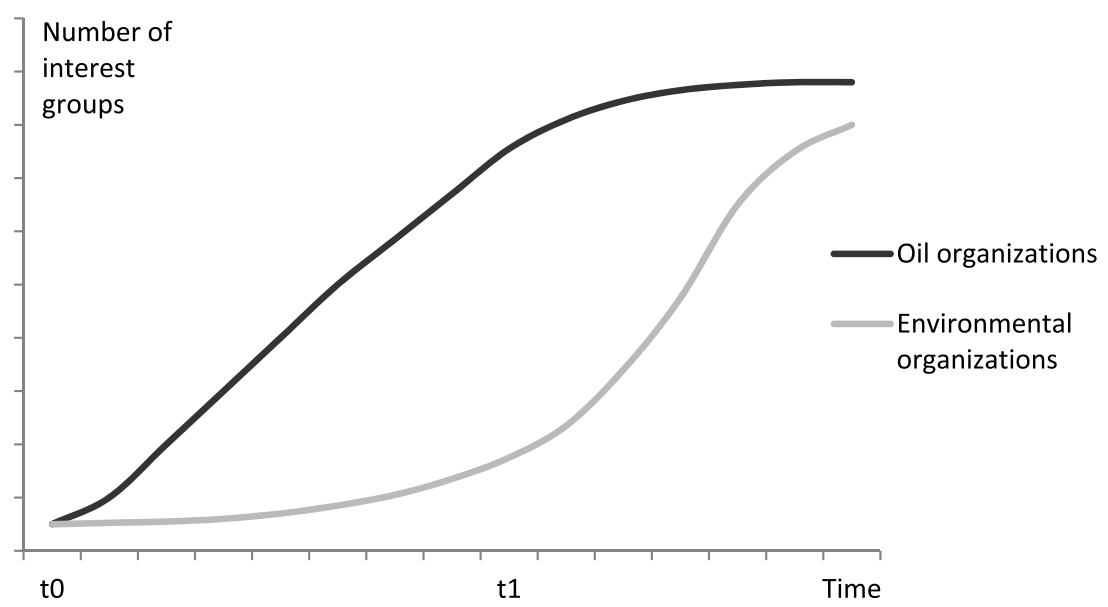

Figure 2

Interest Community Development from the Neopluralist Perspective

has a specific carrying capacity that limits the number of interest groups able to become politically active. ${ }^{18}$ As a result, when more interest groups mobilize in a field and competition becomes more stringent, it becomes harder for new interest groups to find enough resources to become active. As a result the number of interest groups able to mobilize in a particular field will not grow indefinitely. ${ }^{19}$

A way to demonstrate how this works is to hypothesize an interest group community at time $t_{0}$ that only includes oil companies and environmental NGOs (Figure 2). Within this community the number of oil interest groups, due to their relatively better mobilization potential, will initially grow faster than the number of environmental NGOs. However, at some point $\left(t_{1}\right)$, the carrying capacity of oil interest groups will be reached, after which their number will stabilize. However, as the carrying capacity of environmental interest groups has not yet been reached, more of them can still enter the community. In other words, while the number of oil interest organizations after $t_{1}$ grows only marginally or not at all, the number of environmental organizations increasingly grows after $t_{1}$. Thus, during the period $t_{0}-t_{1}$ the interest group community will increasingly skew towards oil interests, while after $t_{1}$ the community will tend to become more diverse again.

Moreover, density is also important when interest groups attend international diplomatic conferences. If an interest group becomes active in a dense interest group community, it is much more likely to stop its lobbying efforts because the added value of its attendance will not always outweigh the costs, in particular when other organizations are representing a similar issue of concern.

18. Lowery and Gray 2004.

19. Hannan and Carroll 1992; Nownes 2004. 
In contrast, when other organizations are not active, the expected benefits of maintaining political activities are higher for a newly attending organization, because the added value of being present is much higher for each individual interest group. As an example, for an environmental interest group that attends a conference where only four other environmental groups are active, the additional benefits of their activities are rather high ( 1 out of 5 , or 20 percent). Yet, if the same organization attends a meeting where fifty other environmental organizations are active, the added benefit of its presence will be much lower (about 2 percent). For this reason, given the costs associated with lobbying, the chance of discontinuing lobbying will increase as a community becomes more densely populated. In the end, other things being equal, denser interest group communities will grow at a slower pace than less densely populated interest group communities; this means that the overall community (all interest groups in a field) may become more balanced over time. In short, due to several factors, neopluralists assume that interest group communities stabilize after a certain period of time. Other things being equal (such as the political agenda), this eventually leads to a more diverse set of interests at political venues, because groups that face more collective action problems will have the opportunity to increase their relative share in the entire interest group community.

Of course, in theory a third option is possible: the development of an interest community without collective action problems or a constant level of skewness over time. This option was first postulated by David Truman (1951) and labeled pluralism. The basic premise of the theory is that grievances in society almost naturally find their way to politicians through interest groups that serve as mediators between citizens and the government. I do not include this option in the analysis because all empirical research on interest group mobilization has revealed that interests face varying levels of collective action problems. Although studies often contradict each other on which types of interests prevail under different circumstances, the fact that there are varying collective action problems for different types of interest groups is nowadays undisputed.

\section{Research Expectations}

In this paper I aim to answer two key questions. First, does the climate change interest group community become more or less skewed over time? Second, can community developments in this field be explained with the collective action or neopluralist perspective? To answer these questions, I analyze the diversity, density, and volatility of the COP interest group community over time.

I first look at the diversity of policy areas for which interest groups are represented at COPs, ${ }^{20}$ to answer whether the set of mobilized groups becomes broader or narrower over time. If the system becomes less diverse over time, this 
confirms the collective action perspective because more similar organizations have occupied the interest groups community. In contrast, more diversity over time supports the neopluralist perspective.

Analyzing diversity only, however, does not adequately test these claims. Therefore, I then compare the mobilization patterns of different types of groups, representing the varying types of collective action problems over time. I focus on two organizational types-business and citizen interests-which generally have the most unequal opportunities to politically organize. ${ }^{21}$ As noted before, it can be assumed that mobilizing business is less problematic than mobilizing citizens, due to the collective action problems they face. ${ }^{22}$ Second, as not all business actors face similar collective action problems, I make a further distinction based on the scope of the business organizations ${ }^{23}$ - those representing specific types of products and those representing more aggregate economic sectors, called "encompassing" associations (see research design). I assume that specific associations face fewer collective action problems than encompassing organizations because they are less inclined to free-ride in economic sectors. ${ }^{24}$

If the collective action perspective is correct, business (especially specific business) interest organizations will dominate the COP interest community, as they face fewer collective action problems, and their dominant position will get reinforced over time. In contrast, according to the neopluralist perspective, we expect to observe such a trend in the first years of community development, but, later on more citizen and encompassing business organizations will mobilize.

Finally, I analyze volatility within the COP interest group community. This concerns the extent to which organizations are able to maintain their lobbying efforts over multiple conferences. A focus on volatility helps to answer the question of increasing or decreasing skewness in the COP interest system, as well as how a collective action or neopluralist perspective explains community development. As Muñoz Cabré argues,

By measuring the number of new organizations, we learn nothing about continued participation from already accredited NGOs... A deeper analysis could offset this limitation with a quantitative and historic analysis of actual participation by delegates, based on the official lists of participants mentioned. ${ }^{25}$

In other words, continued participation at COPs serves as an additional check on how participation skewness developed over time. If organizations with fewer mobilization obstacles-business and specific organizations-develop a consistent lobbying presence at COPs, this indicates that the interest group system has become even more skewed. In contrast, if organizations faced with more

21. Lowery and Gray 2004; Dür and Mateo 2013.

22. Dür and Mateo 2013; Fisher and Green 2004; Fisher 2010.

23. Olson 1965.

24. Gray and Lowery 1996; Halpin and Binderkrantz 2011; Olson 1965.

25. Muñoz Cabré 2011, 17. 
collective action problems-citizen and encompassing organizations-become more regular players, they can compensate for initial collective action problems, which results in a more balanced interest group system. Such a development would be especially relevant for how we understand representation at international climate conferences. By definition, encompassing business groups and citizen organizations have a broader scope in representation. If they maintain their presence, this implies that a broader set of interests gains better representation at international climate conferences.

\section{Research Design and Operationalization}

To assess the development of the COP interest group community, I mapped all interest organizations that attended COPs between 1997 and 2011. ${ }^{26}$ The dataset includes 6,655 organizations that attended one or more COPs since 1997. This number differs substantially from the 1,322 in some earlier accounts of the COP interest group community, ${ }^{27}$ because they included only organizations that had official UNFCCC observers. One important accreditation requirement to becoming an observer at a climate conference is that the organization must be a nonprofit entity, which excludes for-profit business organizations from registering. This, however, does not mean that such firms do not attend these conferences, because a firm may register as a member of an official observer delegation. For instance, Shell and the Dow Chemical Company attend as members of the World Business Council for Sustainable Development, while Siemens and Google attend as part of the Alliance to Save Energy. As the UNFCCC lists each individual participant and its affiliated organization on its website, I was able to identify all the organizations that attended the COP's meetings. Figure 3 lists the total interest groups attending each COP between 1997 and 2011.

The next step included a website search for all these organizations. For most organizations a website provided more elaborate data on the organization. For about 20 percent I was not able to find a website, but information stored on other websites (for instance, from other interest groups who refer to the organization in question) enabled me to code some basic features of these organizations. For less than 5 percent of organizations I could find no information at all. My dataset gives a comprehensive insight into the types of organizations attending COP meetings, the region or countries from which they come, the issue areas in which they are active, their constituency base, and how they are organized. In addition, because data exist on all COPs from 1995 (COP3 in Japan) to 2011 (COP17 in Durban), I was able to account for density, diversity, and stability changes over a substantial period of time.

Next, I turn to the operationalization of the variables (see Table 1). First, to see how diversity develops, I examine the level concentration in the interest

26. Hanegraaff et al. 2011; Halpin and Jordan 2012; Messer et al. 2011; Gray and Lowery 1996; Wonka et al. 2010.

27. Muñoz Cabré 2011; McGregor 2011. 


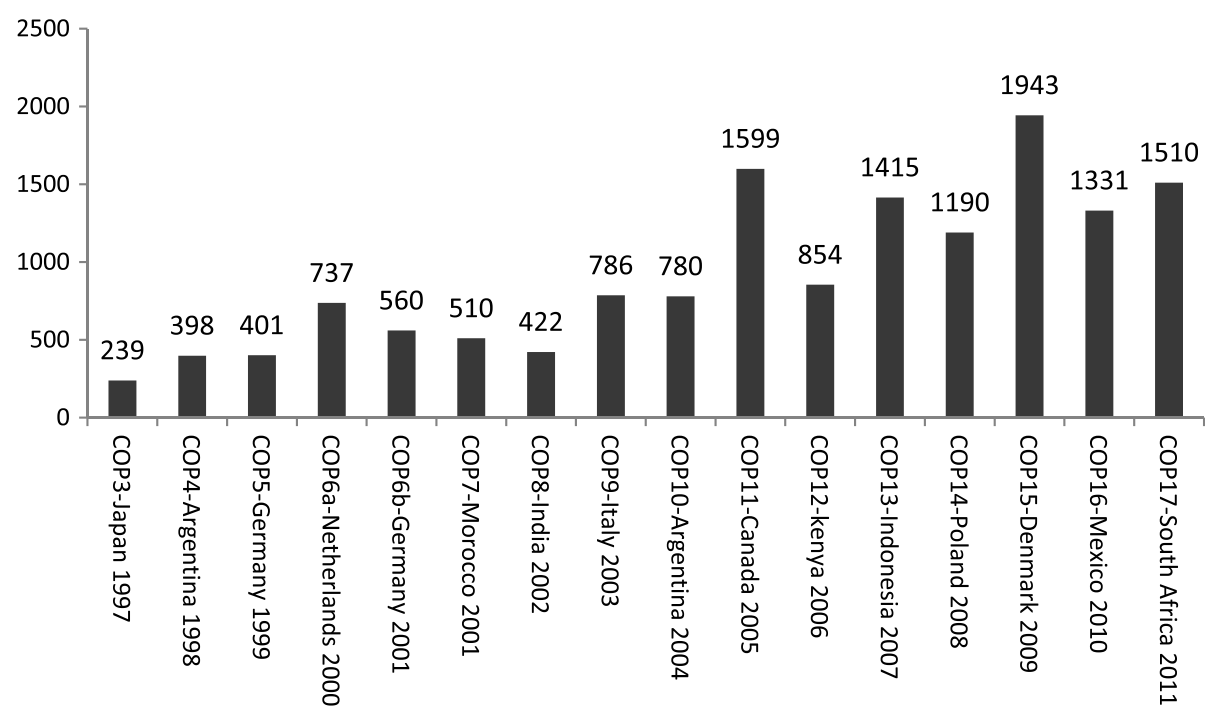

\section{Figure 3}

Number of Interest Groups at COPs, 1997-2011

community over time. Hereby I rely on the Herfindahl index. ${ }^{28}$ A higher score on the index indicates a more concentrated pattern of representation, while a lower number refers to a more diverse pattern of representation at a COP. By analyzing the evolution of interest concentration at each COP, one can see whether representation at COPs becomes more or less diverse over time. However, as the business and citizen interest organizations were coded into different categorical frameworks, I calculated separate Herfindahl scores for the business and citizen issue areas, and I present two analyses regarding the evolution of interest concentration over time; one related to the business sector and one related to citizen interests. The classification for business organizations is based on the International Standard Industrial Classification (ISIC) of All Economic Activities. For this specific analysis each organization was grouped at the one-digit ISIC level, which corresponds with broad economic sectors such as agriculture, construction, transport, communication, and so on. ${ }^{29}$ Citizen groups were categorized according to eight broad fields: environment, development, poverty reduction, human rights, consumer interests, labor, health, and democratic development.

Regarding the development of density, I compare two types of organizational distinctions that are widely associated with the most uneven levels of collective action problems. First, to compare the development of business $(N=2,498)$ and citizen group $(N=2,186)$ participation, I differentiated all organizations that represented either of these organization types at COPs. Business

28. The Herfindahl index is calculated for each COP as the sum of the squared proportions of organizations belonging to a certain business or citizen issue area.

29. For a full list of ISIC sectors see Appendix 1. 
Table 1

Overview of Analyses

\begin{tabular}{|c|c|c|}
\hline Variable & Explanation & Source \\
\hline Diversity development & $\begin{array}{l}\text { Level of concentration in citizen } \\
\text { and business interest communities } \\
\text { (measured by Herfindahl index) }\end{array}$ & ISIC rev.4; WVS \\
\hline Time & Years since COP3 (Japan, 1997) & UNFCCC website \\
\hline Density development & $\begin{array}{l}\text { Temporal growth or decline of selected } \\
\text { interest communities over time }\end{array}$ & UNFCCC website \\
\hline Constituents & $\begin{array}{l}\text { Collective action problems related to } \\
\text { type of constituent: business and } \\
\text { citizen interests }\end{array}$ & Website coding \\
\hline Scope of interests & $\begin{array}{l}\text { Collective action problems related } \\
\text { to size of business sectors: specific } \\
\text { and encompassing }\end{array}$ & $\begin{array}{l}\text { ISIC rev.4; WVS; } \\
\text { Website coding }\end{array}$ \\
\hline Time & Years since COP3 (Japan, 1997) & UNFCCC website \\
\hline Volatility development & $\begin{array}{l}\text { Maintenance of interest groups: } \\
\text { tourists, incidental and regular } \\
\text { attendants. }\end{array}$ & UNFCCC website \\
\hline Constituent & Business and citizen interests & Website coding \\
\hline Scope of interests & Specific and encompassing business & Website coding \\
\hline Time & Years since COP3 (Japan, 1997) & UNFCCC website \\
\hline
\end{tabular}

organizations include associations, such as the International Chamber of Commerce, as well as firms, such as Shell or Toyota. Citizen groups include all organizations that rely, either directly or indirectly, on support from individuals and/or defend interests that transcend the individual economic interests of the supporting constituency (e.g., Greenpeace, Transparency International, or the international alliance Save the Children). I excluded research organizations $(N=1,757)$ because they are funded predominately by the government and therefore confronted with different types of collective action problems. Labor unions $(N=175)$ were omitted due to the low number of cases. I further differentiated between business organizations regarding the scope of issue areas represented. Organizations coded at the ISIC 1 or 2 level were categorized as "encompassing business groups." This includes organizations representing broad economic sectors such as agriculture or communication. Organizations representing issue areas that correspond with ISIC level 3 or 4, such as eggs or civil aviation, were coded as specific business associations.

When analyzing the density development of interest groups, I tested for an alternative explanation, namely the impact of the agenda of the climate conferences. Indeed, in order to reach conclusions about varying lobbying patterns over time, it is crucial to control for whether groups address the same concerns over time. For this reason, I distinctly compared mobilization on issue areas 


\section{Figure 4}

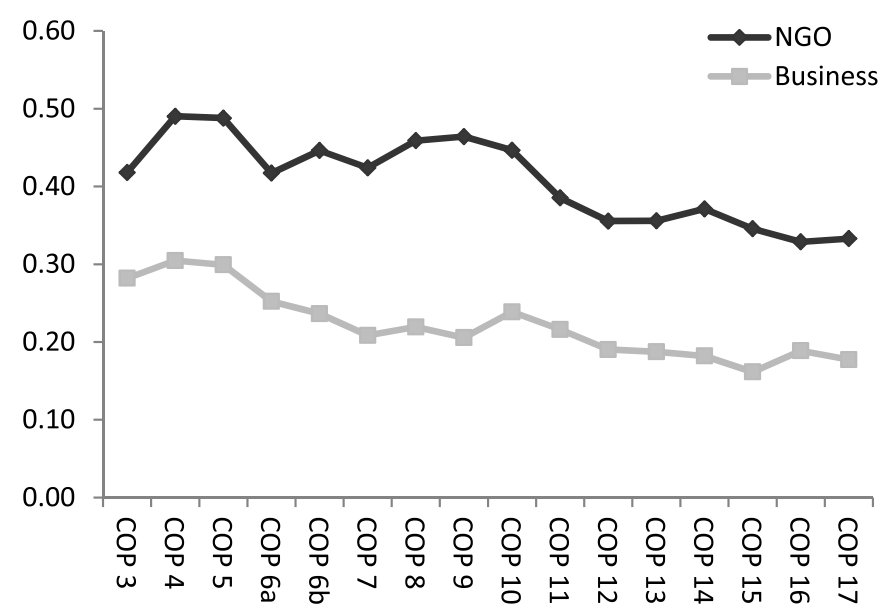

Level of Concentration in Interest Community at COPs: NGO and Business Fields

that were on the agenda of the COP right from the start, such as manufacturing and environment. ${ }^{30}$ Observing stronger mobilization patterns for manufacturing compared to environmental organizations, would indicate that collective action problems are more severe for citizen groups than business groups, irrespective of the policy agenda, because both issue areas were on the agenda of COPs right from the start. A second check concerns the development of specialized and encompassing organizations within specific economic sectors. If specialized business sector interests mobilize more often in the early stages of community development than do more general encompassing groups in the same sector, this would further corroborate the importance of collective action problems.

Finally, to analyze volatility, I constructed three categories that tap the attendance rates of individual organizations at COPs. "Tourists" are organizations that attended only one COP (3,352 organizations). "Incidental participants" attended up to 50 percent of COPs (1,273 organizations). "Regular participants" attended more than 50 percent of COPs (1,010 organizations). For the analysis of interest group volatility, I excluded all organizations that were newcomers at the last three COPs (1,020 organizations), as I could not predict their participation rates over a substantive number of future conferences.

\section{Empirical Analysis}

I first analyze the diversity of the citizen and business interest group communities at COPs. In general, evidence is in line with the neopluralist perspective. ${ }^{31}$

30. Oberthür and Ott 1999; Najam et al. 2003; Yamin and Depledge 2004; Schipper 2006; Newell 2006; Nelson 2009; Muñoz Cabré 2011; Depledge 2013.

31. See also Muñoz Cabré 2011, 20. 
Table 2

Development of Largest Citizen and Business Sectors (Percentage of Total COP)

\begin{tabular}{lrrrrrrrrrrrrrrrr}
\hline COP & 3 & 4 & 5 & $6 a$ & $6 b$ & 7 & 8 & 9 & 10 & 11 & 12 & 13 & 14 & 15 & 16 & 17 \\
\hline ENV & 58 & 65 & 64 & 58 & 62 & 59 & 60 & 63 & 61 & 55 & 47 & 47 & 50 & 47 & 42 & 43 \\
DEV & 20 & 19 & 21 & 17 & 16 & 17 & 23 & 19 & 19 & 19 & 24 & 22 & 22 & 22 & 24 & 23 \\
HR & 9 & 8 & 6 & 16 & 14 & 18 & 10 & 10 & 12 & 16 & 21 & 23 & 21 & 22 & 23 & 24 \\
HEA & 3 & 5 & 4 & 4 & 5 & 3 & 4 & 4 & 4 & 6 & 7 & 5 & 4 & 5 & 6 & 6 \\
ENE & 34 & 31 & 29 & 26 & 22 & 27 & 24 & 24 & 20 & 30 & 22 & 19 & 22 & 18 & 17 & 16 \\
MAN & 26 & 34 & 34 & 31 & 30 & 25 & 26 & 25 & 31 & 20 & 22 & 24 & 21 & 20 & 25 & 25 \\
SER & 9 & 10 & 11 & 22 & 20 & 22 & 25 & 24 & 22 & 18 & 27 & 31 & 27 & 30 & 26 & 26 \\
AGR & 3 & 4 & 3 & 4 & 4 & 3 & 1 & 3 & 5 & 2 & 5 & 6 & 5 & 7 & 5 & 6 \\
\hline
\end{tabular}

ENV=Environment; DEV=Development; HR=Human rights; HEA=Human health; ENE=Energy; MAN=Manufacturing and mining; SER=Services; AGR=Agriculture.

The level of concentration within the business and NGO interest communities (Figure 4) clearly shows a steady decrease for both organizational types, which indicates an increasing diversity of representation at COPs. Table 2 shows the percentages of groups representing the four largest economic or citizen issue areas at each COP. The results clearly show that the distribution of interest group representation is much more diverse at later conferences. To give a few examples, while at early conferences interest groups from the manufacturing and energy sectors and from environmental NGOs constituted approximately 60 percent of the entire interest group community, at later conferences the relative stake of these interest organizations dropped to around 40 percent. In contrast, groups in fields that were only marginally represented in the beginning such as human rights, services, or agriculture at least doubled.

Although there is a clear trend towards more diversity, it is hard to link these patterns to a causal mechanism. Collective action problems alone may not drive the trend; other factors, such as changes in the policy agenda of the COPs, could also be at play. Indeed, during climate change negotiations at COPs there are considerable attention shifts from the original focus on reducing emissions toward an emphasis on carbon sinks, such as REDD, and carbon trading. Shifting agendas could explain, for instance, the increased presence of human rights, development, and service industry organizations. Moreover, during this time period scientific evidence of climate change impacts has improved substantially, which has led to a shift in the agenda of the COP. This shift could also explain why we see, for example, a substantial increase of agricultural representation since COP11 (2005). ${ }^{32}$ As such, the general trend towards more diversity does not necessarily tell us much about the impact of specific obstacles for particular interest groups to become active at COPs, nor does it allow us to pinpoint the effect of density dependency on the 

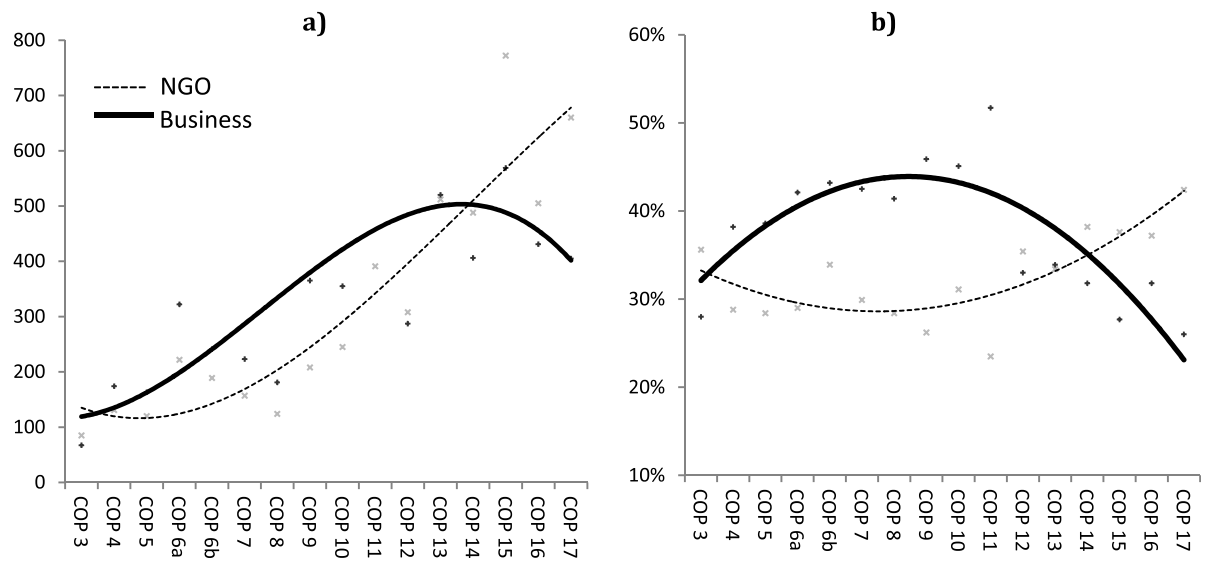

\section{Figure 5}

Business and NGO Group Representation at COPs: Trend Line Absolute (a), and Relative to All Mobilization (b).

development of the COP interest group community. To address this, I therefore analyze the mobilization of different types of interest groups with varying collective action problems.

First, I focus on the type of constituencies that interest groups represent and compare the number of business groups with the number of citizen groups. ${ }^{33}$ Figure 5 plots the absolute and relative development of business and citizen representation at each COP, showing a steady increase in interest group mobilization over time. A closer look at the relative growth rates of both issues areas, however, reveals a substantially different pattern for the attendance rates of citizen and business interest groups. The number of business groups grew substantially faster during the early stages of community development compared to citizen interest groups (Figure 5a). These differences are even clearer in Figure 5b, which presents the growth and decline of the relative share of business and citizen groups across the different COPs. Not until COP11 in 2005 did the number of citizen groups begin to bypass that of business groups. This suggests that collective action problems were less severe for business actors at first. Yet, as the number of business groups grew denser (indicated by the flattening out of the business curve), citizen groups were gradually able to increase their relative stake in the interest community. The UN Climate Conferences started in 1995, implying that the COP interest community was dominated by business interests over a period of about ten years. After COP11 (2005), the number of citizen groups began to grow faster and, finally, surpassed the business groups by COP14 (2008). Combined, these trends fit well with a neopluralist account in which interests that face fewer collective action problems mobilize

33. The percentages in Figure $5 \mathrm{~b}$ do not add to 100 percent because research organizations and labor unions are not included in the figure. 


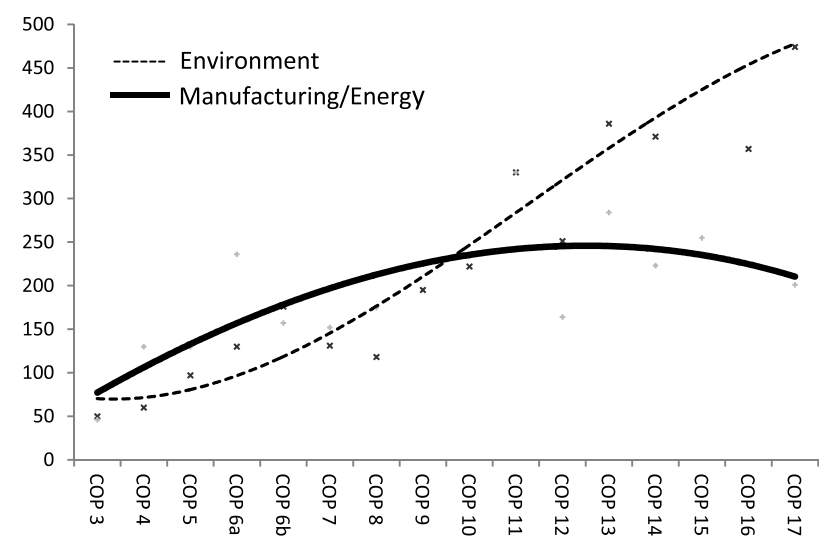

\section{Figure 6}

Development of Environmental and Manufacturing, Mining, and Energy Organizations over Time at COPs (trend line absolute representation)

more easily in the early years of interest group community development, while interests that face more severe collective action problems catch up in the later stages of community development.

To make sure that these results were not caused by changes in the policy agenda (alone), I plotted the mobilization patterns for different areas. In Figure 6 I compare the development of only those business and citizen groups for which their issue area of concern was on the agenda of each COP from the outset, namely business groups in the manufacturing and energy sectors and environmental NGOs. The patterns confirm other results and clearly show that environmental NGOs mobilized more slowly in the initial stages than did business organizations, even for areas always on the COP agenda. First, business groups from the industry sector (organizations representing the manufacturing and energy sectors) outnumbered environmental NGOs until COP10 (2004) indicating that they face fewer obstacles to becoming active during COPs. Second, industrial organizations also reached their mobilization peak (the conference at which the most groups active in a certain issues area are presen) at COP11 (2005), whereas environmental NGOs have apparently not even reached their full potential, indicated by the still increasing trend line over the last COPs. Combined, these results confirm that business groups faced fewer obstacles to becoming active at COPs, a finding that is much in line with the causal mechanisms identified by neopluralist scholarship.

For the second analysis I compare the mobilization of business organizations in terms of their scope: whether they are specific or encompassing. Figure 7 shows the results in terms of absolute and relative growth. In general, we see an increase in both types of interest groups but a clear difference in how specific and encompassing interests mobilized. Specific interests were relatively more active during the early stages of the development of the COP interest group community (see specific business trend line), which indicates that, as expected, 
a)

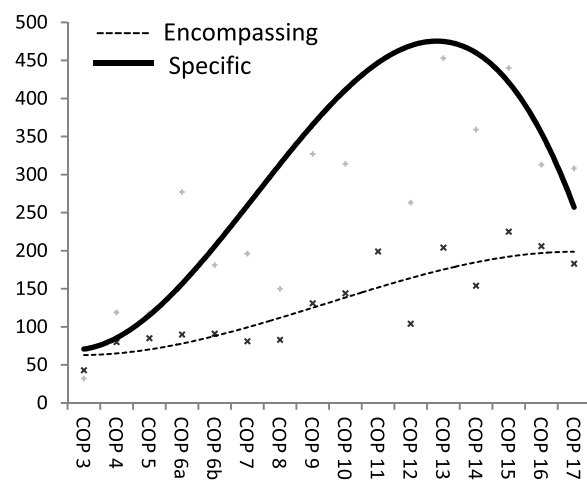

b)

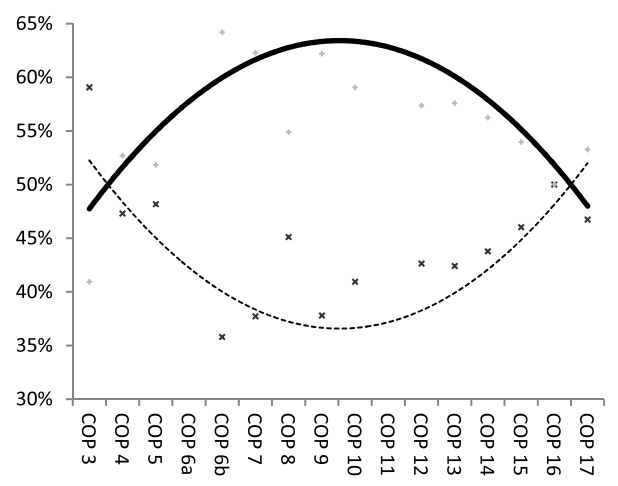

Figure 7

Specific and Encompassing Business: Trend Line Absolute (a) and Relative (b) at COPs

they faced less severe collective action problems. Nevertheless, encompassing business interests gained more prominent representation over time, as their relative share in the COP interest group community increased. The turning point for encompassing organizations followed COP11 in 2005, indicating that their collective action problems were not easy to overcome. Their eventual increase in relative share of the COP interest community fits the neopluralist expectation.

I controlled for whether specialized or encompassing business organizations within similar economic sectors show different trends. By focusing on individual sectors rather than aggregate patterns, I can account for the varying policy agenda of the COPs. The results are quite striking (Figure 8). In all four business fields specialized interest groups mobilized much more often at early COPs, whereas the number of encompassing groups grew faster at later COPs. For the COP agenda, manufacturing and energy interests mobilized early because these issues were on the agenda right from the start, whereas the encompassing groups representing these economic sectors become more active during latter conferences. For services and agriculture, issue areas that were much less prominent on early COPs, we see that specialized and encompassing groups were barely represented at early COPs, but when these fields became more active, specialized groups mobilized quickly, while more encompassing groups picked up the pace only during the last few conferences. These results clearly fit into a neopluralist perspective in which the interest group system is at first occupied by specialized interests, whereas over time a broader set of organizations finds its way in.

The final part of my empirical analysis focuses on volatility: presence at COPs over time. Table 3 shows COP attendance by different types of organizations. ${ }^{34}$

34. Because at least one nominal variable is involved in all three comparisons (group type, scope, and alignment), I use Cramér's V as the measure of association. 
- Transnational Advocacy over Time
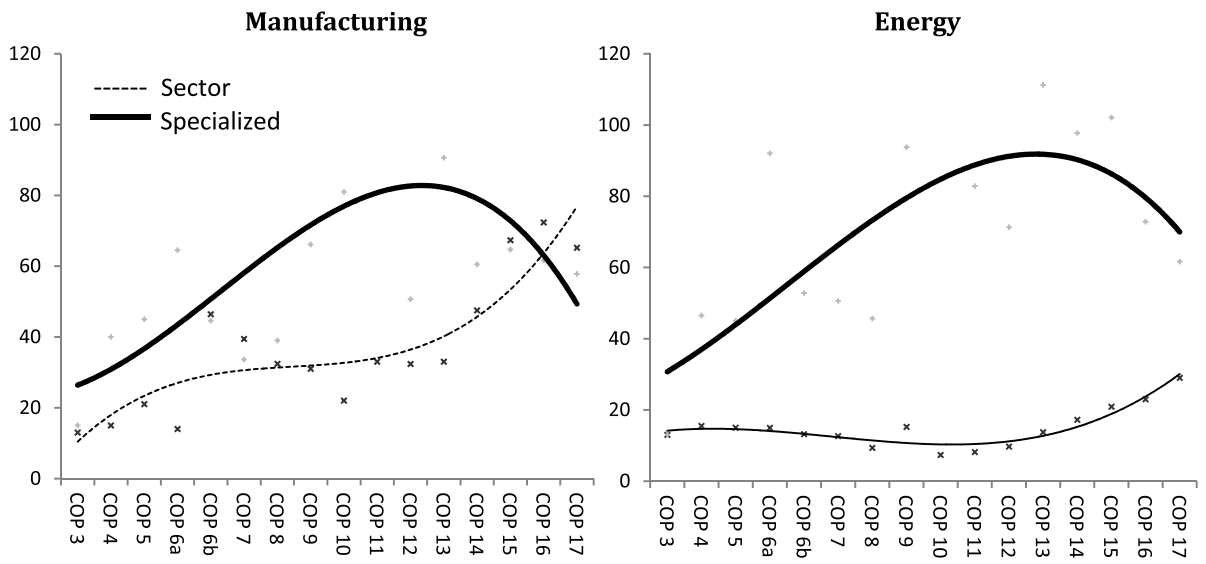

Services

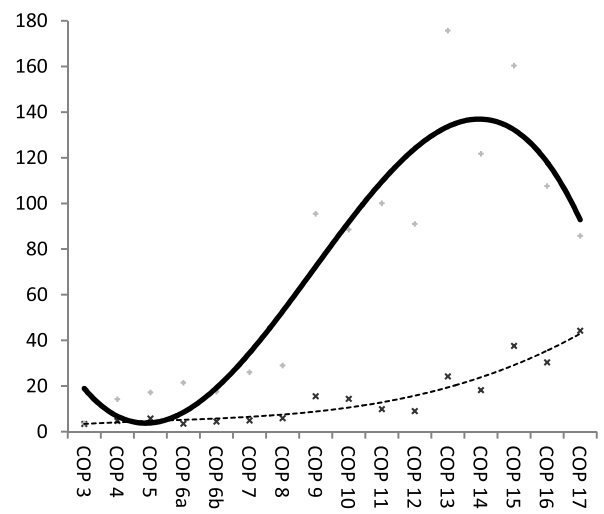

Agriculture

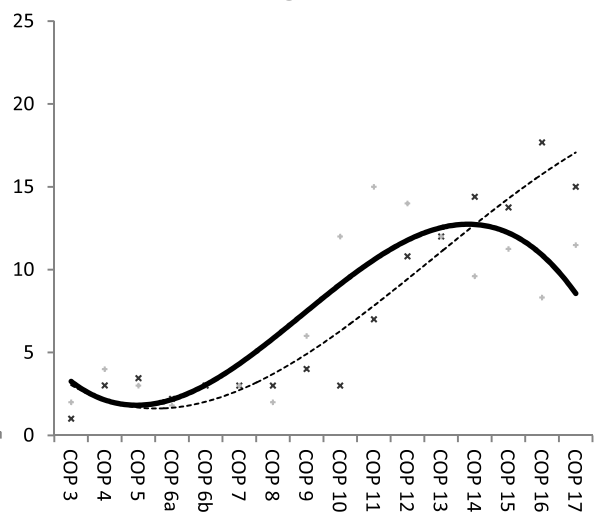

Figure 8

Development of Specific and Specialized in Four Economic Sectors: Trend Line Absolute Mobilization at COPs

\section{Table 3}

Attendance Percentages by Group Type and Issue Scope

Tourist Incidental Regular Cramér's V

\section{Organization type}

Business

Citizen

$64 \%$

$22 \%$

$13 \%$

Scope of issue

Specific

$55 \%$

$26 \%$

$18 \%$

$p<.000$

Encompassing

$69 \%$

$20 \%$

$10 \%$

.208

$51 \%$

$27 \%$

$22 \%$

$p<.000$ 
The results clearly fit into a neopluralist perspective. Citizen and encompassing business groups maintained a steadier lobbying presence, while the presence of business organizations and specific business groups was much more volatile. More specifically, citizen and encompassing business groups (organizations facing more collective action problems) maintained a steadier lobbying presence at COPs. For citizen groups, 44 percent were either incidental or regular attendants (26 incidental plus 18 regular participants), while for business organizations only 35 percent were (Cramér's $V=.190$ ). For specific business organizations the difference is somewhat more substantial (Cramér's V = .208). Of the encompassing business organizations, 49 percent were incidental or regular participants at COPs, while only 30 percent of specific business organizations attended multiple COPs. These results indicate that citizen and encompassing business groups, although they were latecomers to COPs, developed over time more steady lobbying activities compared to business and more specialized interest organizations. This could, to some extent, have compensated for their initial lack of mobilization because they were able to create more lasting networks, gain increased experience and, potentially, have better access opportunities and/or options to impact decision-making. This trend, again, fits into a neopluralist logic, as it led to a more balanced interest community over time in terms of the potential to effectively represent constituents at climate summits.

\section{Conclusions}

The results presented in this paper address a key question in the transnational advocacy literature: the effect of opening up international organizations and institutions to societal input. The call for more openness towards interest groups has found much resonance in academic circles. Both proponents and opponents assume that interest communities at IOs develop in a certain way. ${ }^{35}$ Rather than assume a certain development of an interest group community, this article analyzed how an actual transnational interest group community did develop over time.

According to my findings, neither opponents nor proponents of more openness are particularly accurate in their expectations on how transnational interest communities develop. From a longitudinal angle the proponents of more openness were more accurate, as the COP interest community did indeed become more diverse in the long run. However, for the first decade of community development, I observed a trend more in line with what the opponents of more openness of IOs expected: that some organizational types-in particular specialized interestswere much more dominant than others and became increasingly so over this time period. This finding could have had important implications, because organizations with fewer collective action problems may have enjoyed certain advantages 
during the very early stages of the development of the COP interest group community. ${ }^{36}$ And, as many institutional and decision-making procedures are decided on when international organizations are young, specific business interests may also have created vital path dependency structures that continue to benefit them.

A second conclusion is that the development of the COP interest community shows remarkable similarities with the development of domestic interest group communities. While I do not imply that domestic and transnational advocacy are the same, there may be some resilience in the development of interest group communities that transcends particular political systems. For instance, as observed in domestic systems, business organizations, and particularly specialized business organizations, were able to become active much more quickly than other types of interest organizations. ${ }^{37}$ As in domestic systems, these initial advantages did not lead to increasingly skewed interest group communities in the long run. ${ }^{38}$ Although the data presented in this article do not allow me to isolate whether such similar developments were always driven by the same factors (i.e., collective action problems, density dependency), the similarities are striking. We need to pay more attention to theories of community development when aiming to describe how and why transnational interest communities develop.

I have discussed how the COP interest community developed and proposed several likely causes for its evolution, but the precise consequences of these developments remain to be seen. While research in other political systems shows a link between the density of interest group communities and the potential of interest groups to influence political decision-making, we cannot simply assume that the same also applies to climate conferences. ${ }^{39}$ This is something we need to explore further in future research. Second, counting interest groups is not a perfect measure for determining which interests are represented at climate conferences. Indeed, some interest groups represent narrow interests, while others represent very broad societal segments. ${ }^{40}$ While I dealt with this issue from an aggregate perspective, i.e. between specialized and encompassing business organizations, more attention in future research should be given to the question of whom all these different groups actually (claim to) represent. For instance, one could do case studies on the representative nature of certain specialized and encompassing business groups and NGOs to see whom they actually represent. This would allow for a more nuanced understanding of interest representation at COPs, This study should be interpreted as a first step in a search to better understand the impact of opening up IOs to interest groups.

36. Heinz et al. 1993; Berkhout and Lowery 2011.

37. Baumgartner and Leech 2001; Gray and Lowery 1996.

38. Lowery et al. 2008; Berkhout and Lowery 2011.

39. Baumgartner et al. 2009; Mahoney and Baumgartner 2015.

40. Halpin and Jordan 2012. 


\section{References}

Baumgartner, Frank, and Beth Leech. 2001. Interest Niches and Policy Bandwagons: Patterns of Interest Group Involvement in National Politics. Journal of Politics 63 (4): 1191-1213.

Baumgartner, F. R., J. M. Berry, M. Hojnacki, B. L. Leech, and D. C. Kimball. 2009. Lobbying and Policy Change: Who Wins, Who Loses, and Why. University of Chicago Press.

Berkhout, Joost, and David Lowery. 2011. Short-Term Volatility in the EU Interest Community. Journal of European Public Policy 18 (1): 1-16.

Berry, Jeffrey. 1999. The New Liberalism. The Rising Power of Citizen Groups. Washington: Brookings Institution Press.

Bexell, Magdalena, Jonas Tallberg, and Anders Uhlin. 2010. Democracy in Global Governance: The Promises and Pitfalls of Transnational Actors. Global Governance 16 (1): 81-101.

Beyers, Jan, Reiner Eising, and William Maloney. 2008. Researching Interest Group Politics in Europe and Elsewhere: Much We Study, Little We Know? West European Politics 31 (6): 1103-1128.

Braun, Caelesta. 2012. The Captive or the Broker? Explaining Public Agency-Interest Group Interactions. Governance 25 (2): 291-314.

Carpenter, Daniel. 2004. Protection without Capture: Product Approval by a Politically Responsive, Learning Regulator. American Political Science Review 98 (4): 613-631.

Charnovitz, Steve. 2000. Opening the WTO to Non-Governmental Interests. Fordham International Law Journal 24 (1): 1-46.

Depledge, Joanna. 2013. The Organization of Global Negotiations: Constructing the Climate Change Regime. London: Routledge.

Dür, Andreas, and Gemma Mateo. 2013. Gaining Access or Going Public? Interest Group Strategies in Five European Countries. European Journal of Political Research 52 (5): 660-686.

Fisher, Dana. 2010. COP 15 in Copenhagen: How the Merging of Movements Left Civil Society Out in the Cold. Global Environmental Politics 10 (2): 12-17.

Fisher, Dana, and Jessica Green. 2004. Understanding Disenfranchisement: Civil Society and Developing Countries' Influence and Participation in Global Governance for Sustainable Development. Global Environmental Politics 4 (3): 65-84.

Fried, Jonathan. 1997. Globalization and International Law - Some Thoughts for States and Citizens. Queen's Law Journal 23: 259-274.

Gray, Virginia, and David Lowery. 1996. A Niche Theory of Interest Representation. The Journal of Politics 58 (1): 91-111.

Hanegraaff, Marcel, Jan Beyers, and Caelesta Braun (2011). Open the Door to More of the Same? The Development of Interest Group Representation at the WTO. World Trade Review 10 (4): 447-472.

Halpin, Darren, and Anne Binderkrantz. 2011. Explaining Breadth of Policy Engagement: Patterns of Interest Group Mobilization in Public Policy. Journal of European Public Policy 18 (2): 201-219.

Halpin, Darren, and Herschel Thomas III. 2012. Evaluating the Breadth of Policy Engagement by Organized Interests. Public Administration 90 (3): 582-599.

Halpin, Darren, and Grant Jordan. 2012. The Scale of Interest Organization in Democratic Politics: Data and Research Methods. New York: Palgrave Macmillan.

Hannan, Michael, and Glenn Carroll. 1992. Dynamics of Organizational Populations. NY: Oxford University Press. 
Heinz, John, Edward Laumann, Robert Nelson, and Robert Salisbury. 1993. The Hollow Core: Private Interests in National Policy Making. Cambridge: Harvard University Press.

Jönsson, Christer, and Jonas Tallberg, eds. 2010. Transnational Actors in Global Governance: Patterns, Explanations, and Implications. Basingstoke: Palgrave.

Lowery, David. 2007. Why Do Organized Interests Lobby? A Multi-Goal, Multi-Context Theory of Lobbying. Polity 39 (1): 29-54.

Lowery, David, and Virginia Gray. 1996. The Population Ecology of Interest Representation Lobbying Communities in the American States. Ann Arbor: University of Michigan Press.

Lowery, David, and Virginia Gray. 2004. A Neopluralistic Perspective on Research on

Organized Interest. Political Research Quarterly 57 (1): 163-175.

Lowery, David, Virginia Gray, and James Monogan. 2008. The Construction of Interest Communities: Distinguishing Bottom-Up and Top-Down Models. Journal of Politics 70 (4): 1160-1176.

Mahoney, Christine, and Michael Beckstand. 2011. Following the Money: European Union Funding of Civil Society Organizations. Journal of Common Market Studies 49 (6): 1339-1361.

Mahoney, Christine, and F. R. Baumgartner. 2015. Partners in Advocacy: Lobbyists and Government Officials in Washington. Journal of Politics. Forthcoming.

McGregor, Ian. 2011. Disenfranchisement of Countries and Civil Society at COP 15 in Copenhagen. Global Environmental Politics 11 (3): 1-7.

Messer, Anne, Joost Berkhout, and David Lowery. 2011. The Density of the EU Interest System: A Test of the ESA Model. British Journal of Political Science 41 (1): 161-190.

Muñoz Cabré, Miquel. 2011. Issue-linkages to Climate Change Measured through NGO Participation in the UNFCCC. Global Environmental Politics 11 (3): 10-22.

Najam, Adil, Saleemul Huq, and Youba Sokona. 2003. Climate Negotiations beyond Kyoto: Developing Countries' Concerns and Interests. Climate Policy 3 (3): 221-231. Nelson, Gerald C. (ed.) 2009. Agriculture and Climate Change: an Agenda for Negotiation in Copenhagen. International Food Policy Research Institute, Volume 16.

Newell, Peter. 2006. Climate for Change: Non-State actors and the Global Politics of the Greenhouse. Cambridge: Cambridge University Press.

Nownes, Anthony. 2004. The Population Ecology of Interest Group Formation: Mobilizing for Gay and Lesbian Rights in the United States, 1950-98. British Journal of Political Science 34 (1): 49-67.

Nownes, Anthony, and Daniel Lipinski. 2005. The Population Ecology of Interest Group Death: Gay and Lesbian Rights Interest Groups in the United States, 1945-98. British Journal of Political Science 35 (2): 303-319.

Oberthür, Sebastian, and Hermann Ott. 1999. The Kyoto Protocol: International Climate Policy for the 21st Century. New York: Springer.

Olson, Mancur. 1965. The Logic of Collective Action: Public Goods and the Theory of Groups. Cambridge: Harvard University Press.

Salisbury, Robert. 1969. An Exchange Theory of Interest Groups. Midwest Journal of Political Science 13 (1): 1-32.

Schattschneider, Eric. 1960. The Semisovereign People: A Realist's View of Democracy in America. Hinsdale: The Dryden Press. 
Schipper, Lisa. 2006. Conceptual History of Adaptation in the UNFCCC Process. Review of European Community \& International Environmental Law 15 (1): 82-92.

Scholte, Jan-Aart. 2000. Civil Society and Democratically Accountable Global Governance. Government and Opposition 39 (2): 211-233.

Spiro, Peter. 2000. The New Sovereigntists: American Exceptionalism and Its False Prophets. Foreign Affairs 79 (9): 9-12.

Truman, David. 1951. The Governmental Process: Political Interests and Public Opinion. New York: Alfred A. Knopf.

Walker, Jack. 1983. The Origins and Maintenance of Interest Groups in America. The American Political Science Review 77 (2): 390-406.

Wonka, Arndt, Frank Baumgartner, Christine Mahoney, and Joost Berkhout. 2010. Measuring the Size and Scope of the EU Interest Group Population. European Union Politics 11 (3): 463-476.

Yamin, Farhana, and Joanna Depledge. 2004. The International Climate Change Regime: A Guide to Rules, Institutions and Procedures. Cambridge UK: Cambridge University Press. 


\section{Appendix 1}

Top-level Business Sectors by UN ISIC code

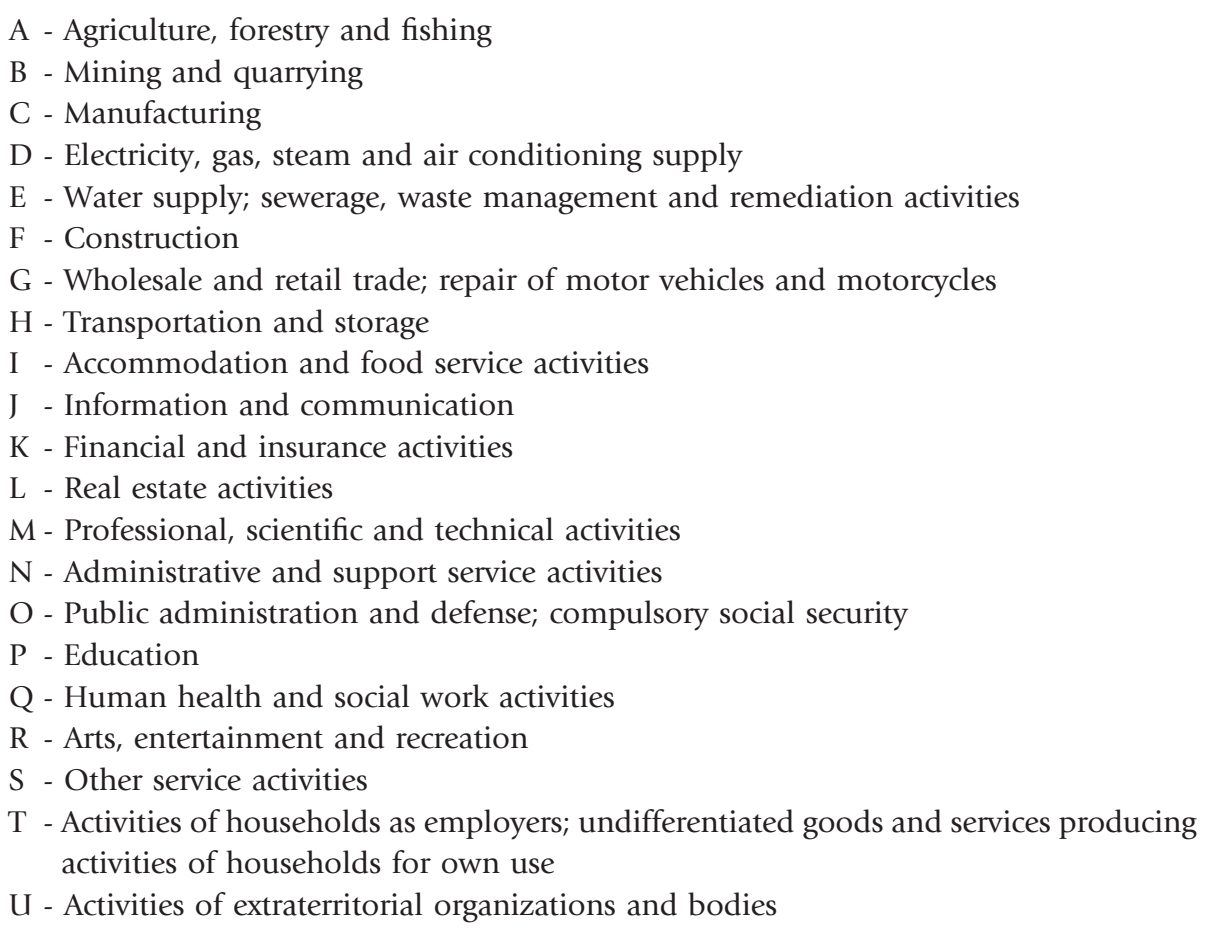

See http://unstats.un.org/unsd/cr/registry/regcst.asp?Cl=27 for a more detailed description of this classification. 
Copyright of Global Environmental Politics is the property of MIT Press and its content may not be copied or emailed to multiple sites or posted to a listserv without the copyright holder's express written permission. However, users may print, download, or email articles for individual use. 